\title{
Introduction: The face of Italy as source of inspiration in the geological sciences
}

So vast is Italy's collection of geological forms, structures and phenomena that they have attracted the attention of naturalists since ancient times. Indeed, such have been the discoveries and contributions made in Italy that Charles Lyell was motivated to write in his Principles of Geology that the Italians "preceded the naturalists of other countries in their investigations into the ancient history of the earth". He thought that they still maintained a decided pre-eminence.

With its position in the centre of the Mediterranean, Italy has always been a preferred destination for geologists coming from different parts of the world, attracted by the extraordinary range of geological situations present in the country. Experience with Italian outcrops and landscapes has been an important element in the development of scientific concepts in general.

The varied geology of Italy results from a long history that has produced a unique geodynamic setting, distinguished by the presence of bivergent Alpidic fold belts with two thrust systems directed respectively towards the European and Adria-African forelands, and their associated centres of igneous activity. The opposing thrust fronts of the two mountain chains, the Alps and Apennines, are characterized by a series of orogenic arcs whose convexity faces their respective forelands and whose concave faces are occupied by internal collapse basins (e.g., the Tyrrhenian Sea).

Great precursors. Two thousand years ago, the Latin poet Ovid (43 BC-AD 17) in his great hexametric poem Metamorphoses noted the importance of the continual mutation of biological forms, of the earth's surface geography and of its geology. In his verses (XV, 262-265) he sketched out a preliminary model of sedimentary cycles:

"Vidi ego, quod fuerat quondam solidissima tellus, / esse fretum, vidi factas ex aequore terras, / et procul a pelago conchae iacuere marinae, / et vetus inventa est in montibus ancora summis."

("I have myself seen what was once most solid ground disappear into the sea, and have heard of land risen out of the sea; marine shells lay far from the sea, and an ancient anchor rested on top of a mountain.")

The Florentine poet Giovanni Boccaccio (1313-1375) wrote in 1340 that fossil shells in the Tuscany hills had formerly lived in the sea that once covered the land. However, the first person to recognize the organic nature of fossils was the Tuscan monk Ristoro d'Arezzo (1239-1282) whose encyclopaedic manuscript La composizione del mondo (The composition of the world) appeared in 1282.
This great naturalist also understood that flowing waters erode the valleys, transport loose materials and deposit them in depressions that then become alluvial plains.

The precursor of the modern science of geology, and of modern methods of scientific inquiry, can fairly be said to have been the incomparable Tuscan genius and polymath Leonardo da Vinci (1452-1519) who collected many penetrating and perspicacious observations that enabled him to acquire a coherent, synthetic vision of geological phenomena, which he expressed in his notes, diagrams, doodles, designs and objective drawings of natural phenomena, which were originally written for his own benefit and not for immediate publication, as well as in his paintings. Unfortunately, the lack of publication of his works in any coherent form prevented his extraordinary contribution to geology from becoming known to his contemporaries and immediate successors. Indeed, some of the Leonardian codexes have become familiar only in recent times. He was the first to recognize that terrestrial landscapes are modelled by fluvial erosion and was well aware that the fossil shells found on the highest Apennine peaks are the remains of living organisms from the sea, which once inundated large parts of northern Italy that were later uplifted to form the mountains. He was also the first to demonstrate the ability of present-day causes to explain the origins of geological phenomena and to coin the term "folding" with respect to rocks structure. Could the enigmatic smile of the Monna Lisa, backed by a landscape sculpted by erosion, reflect the painter's recognition of the importance of stream channels in the formation of landscapes? In another celebrated painting, The Virgin and Infant Jesus with Saint Anne, which hangs in the Louvre, Leonardo depicted with extraordinary precision two turbidite sequences (see G.B. Vai).

The cooling of the Earth, the oldest hypothesis of terrestrial dynamics, was proposed towards the end of the 16th century by Giordano Bruno (1548-1600), a natural philosopher who was burned at the stake in Rome by the Inquisition, perhaps also for having insisted that the Earth orbits around the sun. He also had the temerity to associate the seasons with the Earth's rotation (1584).

It is thus not surprising that in a manuscript of 1603 the first person to use the term "geology" in a scientific sense was the Bolognese naturalist Ulisse Aldrovandi (1522-1605).

The Danish naturalist Niels Steensen (1638-1686), whose name was Latinized to Nicholaus Steno and Italian- 
ized to Niccolò Stenone, was appointed physician to the Grand-Duke of Tuscany, Ferdinand II. In but a few years, 1666-1669, this brilliant man brought his researches into the origins of the Tuscan landscape to fruition with the publication of his Prodromus (1669), literally "Introduction to a Dissertation", a concise work of 76 pages and a masterpiece of inductive logic. In this great milestone in the history of geology, he set down the foundations of modern geological theory on the basis of his field observations. He enunciated three basic stratigraphical principles-superposition, original horizontality and original lateral continuity of bedswhich enabled a relative sequence of geological events to be worked out. In 1988, Steno was beatified by the Catholic Church for his work as an apostolate missionary and Bishop in northern Germany, Denmark and Norway during the years after his great geological discoveries. He lies buried in the church of San Lorenzo in Florence.

In 1760, the term "geology" was used for the first time in its modern sense by Giovanni Arduino (1714-1795) of Verona, an inspired fieldworker and one of the leading pioneers of modern geology. In 1759, after a long period of study in Tuscany, Vicenza and Verona, he set down the fundamental tenets of the modern chronostratigraphical scale. A full thirty years ahead of A.G. Werner in Saxony, he was the first to subdivide Earth history into four "general and successive orders" characterized by terrains that he called Primary, Secondary, Tertiary and Quaternary, as the geological eras are known today. He considered each of these four main layers or orders to be composed of a large quantity of minor layers.

Another great forerunner, who anticipated the geodynamic theories propounded by James Hutton in 1785, was the Venetian Abbot Anton Lazzaro Moro (1687-1764). In 1740 , he argued that physiographic relief results from expansional movements in the interior of the Earth.

If one can argue that the field of stratigraphy was largely invented in Italy, much the same can be said of the study of natural hazards, which are of course particularly active throughout the Italian peninsula. Large explosive eruptions are called plinian in recognition of the first surviving description of an eruption, that of Vesuvius in $\mathrm{AD} 79$, as observed by Pliny the Younger. In two letters written to Tacitus sixteen years after the event, he described the death of his uncle Pliny the Elder, the famous naturalist and author of the 37-volume Historia Naturalis, who like many inhabitants of Pompeii and Herculaneum was mown down by pyroclastic flows.

Much later, the Milanese seismologist and vulcanologist Giuseppe Mercalli (1850-1914) systematically described earthquake damage, using what came to be known as the Mercalli scale, with its ten categories of increasing intensity. It is also worth remembering the work of the pioneer Macedonio Melloni (1798-1854), who demonstrated in 1856 that rocks become permanently magnetized when they cool down. To cap it all, the world's first vulcanological observatory was founded in 1841 on the flanks of Mount Vesuvius by order of the Bourbon King of Naples, Ferdinando II .

Lastly, let us not forget the work of the violinist and geologist of Parma, Roberto Mantovani (1854-1933), who was the Italian consul on the island of Réunion. In 1889 and 1909, he espoused ideas on continental displacement that were remarkably similar to those later propounded by Alfred Wegener. He believed in an expanding Earth (see G. Scalera).

This special issue comprises a selection of nineteen short, synthetic articles on Italian geology. It is merely a sample from a much larger selection that we are offering to the participants who come to Italy in August 2004 for the 32 IGC. Enjoy the articles and see you in Florence!

\author{
Forese Carlo Wezel \\ Editor of this special issue dedicated to \\ aspects of the geology of Italy, site of \\ the 32nd International Geological Congress
}

